\title{
Correction to: COVID-19-associated acute cerebral venous thrombosis: clinical, CT, MRI and EEG features
}

\author{
Fabian Roy-Gash ${ }^{1 *}$, Marine De Mesmay ${ }^{1}$, Jean-Michel Devys ${ }^{1}$, Hervé Vespignani ${ }^{2}$, Raphaël Blanc ${ }^{3}$ and \\ Nicolas Engrand ${ }^{1}$
}

\section{Correction to: Crit Care (2020) 24: 419 https://doi.org/10.1186/s13054-020-03131-x}

Following publication of the original article [1], the authors identified an error in five author names. The given name and family name were erroneously transposed.

The incorrect author names are:

De Mesmay Marine

Devys Jean-Michel

Vespignani Herve

Blanc Raphael

Engrand Nicolas

The correct author names are:

Marine De Mesmay

Jean-Michel Devys

Hervé Vespignani

Raphaël Blanc

Nicolas Engrand

The author group has been updated above and the original article [1] has been corrected.

\author{
Author details \\ ${ }^{1}$ Neuro-Intensive Care Unit, Fondation Ophtalmologique Adolphe de \\ Rothschild, 29 rue Manin, 75019 Paris, France. ${ }^{2}$ Serenity Medical \\ Services-NeuroPhy, ICM-iPEPS, 47-85 Boulevard de l'Hôpital, 75013 Paris, \\ France. ${ }^{3}$ Department of Interventional Neuro-Radiology, Fondation \\ Rothschild, 29 rue Manin, 75019 Paris, France. \\ Published online: 28 August 2020 \\ Reference \\ 1. Roy-Gash F, Marine DM, Jean-Michel D, et al. COVID-19-associated acute \\ cerebral venous thrombosis: clinical, CT, MRI and EEG features. Crit Care. \\ 2020;24:419. https://doi.org/10.1186/s13054-020-03131-x.
}

* Correspondence: froygash@for.paris

${ }^{1}$ Neuro-Intensive Care Unit, Fondation Ophtalmologique Adolphe de Rothschild, 29 rue Manin, 75019 Paris, France

Full list of author information is available at the end of the article

C C The Author(s). 2020 Open Access This article is licensed under a Creative Commons Attribution 4.0 International License, which permits use, sharing, adaptation, distribution and reproduction in any medium or format, as long as you give appropriate credit to the original author(s) and the source, provide a link to the Creative Commons licence, and indicate if changes were made. The images or other third party material in this article are included in the article's Creative Commons licence, unless indicated otherwise in a credit line to the material. If material is not included in the article's Creative Commons licence and your intended use is not permitted by statutory regulation or exceeds the permitted use, you will need to obtain permission directly from the copyright holder. To view a copy of this licence, visit http://creativecommons.org/licenses/by/4.0/ The Creative Commons Public Domain Dedication waiver (http://creativecommons.org/publicdomain/zero/1.0/) applies to the data made available in this article, unless otherwise stated in a credit line to the data. 